\title{
Patterns of Batrachochytrium dendrobatidis transmission between tadpoles in a high-elevation rainforest stream in tropical Australia
}

\author{
Mattias Hagman ${ }^{1,2, *}$, Ross A. Alford ${ }^{1}$ \\ ${ }^{1}$ College of Marine and Environmental Science, James Cook University, Townsville, QLD 4811, Australia \\ ${ }^{2}$ Present address: School of Biological, Earth and Environmental Sciences, The University of New South Wales, Sydney, \\ NSW 2052, Australia
}

\begin{abstract}
The highly virulent fungal pathogen Batrachochytrium dendrobatidis $(B d)$ poses a global threat to amphibian biodiversity. Streams and other water bodies are central habitats in the ecology of the disease, particularly in rainforests where they may transport and transmit the pathogen and harbor infected tadpoles that serve as reservoir hosts. We conducted an experiment using larval green-eyed tree frogs Litoria serrata in semi-natural streamside channels to test the hypotheses that (1) the fungus can be transmitted downstream in stream habitats and (2) infection affects tadpole growth and mouthpart loss. Our results showed that transmission can occur downstream in flowing water with no contact between individuals, that newly infected tadpoles suffered increased mouthpart loss in comparison with controls that were never infected and that infected tadpoles grew at reduced rates. Although recently infected tadpoles showed substantial loss of mouthparts, individuals with longstanding infections did not, suggesting that mouthparts may re-grow following initial loss. Our study suggests that any management efforts that can reduce the prevalence of infections in tadpoles may be particularly effective if applied in headwater areas, as their effects are likely to be felt downstream.
\end{abstract}

KEY WORDS: Amphibian declines $\cdot$ Infection $\cdot$ Larvae $\cdot$ Pathogen $\cdot$ Reservoir Resale or republication not permitted without written consent of the publisher

\section{INTRODUCTION}

Approximately one-third of the world's amphibians are threatened with extinction (Stuart et al. 2004, Collins \& Crump 2009). Outbreaks of chytridiomycosis, caused by the fungal pathogen Batrachochytrium dendrobatidis (hereafter referred to as $B d$ ), are one of the major causes of declines (Berger et al. 1998, Alford \& Richards 1999, Stuart et al. 2004, Lips et al. 2006, Alford 2010). Bd is transmitted by aquatic zoospores (Berger et al. 1998, Longcore et al. 1999, Berger et al. 2005), and during epizootics, $B d$ can spread in terrestrial habitats far from water (McDonald \& Alford 1999, Lips et al. 2006, Brem \& Lips 2008).
Under such circumstances, humidity and ambient temperature have a strong influence on the prevalence and intensity of $B d$ infections (McDonald et al. 2005, Woodhams \& Alford 2005). High temperatures affect the survival of $B d$ itself and the immune defences of frogs (Woodhams et al. 2003, Berger et al. 2004, Richmond et al. 2009). Because of this sensitivity to ambient temperatures, $B d$ prevalence often changes seasonally. For example, in the upland rainforests of northeastern Australia, Bd prevalence in frogs is often higher during the cool, dry winter months and lower in the warm, wet summer months (McDonald et al. 2005, Woodhams \& Alford 2005). When $B d$ is enzootic, transmission may be more con- 
fined to aquatic and riparian environments (Brem \& Lips 2008), where the zoospores may survive for several weeks in the water without an amphibian host (Johnson \& Speare 2003). Compared to the surrounding terrestrial environment, streams are typically cool and thermally stable, and these conditions are favourable for $B d$ (Woodhams et al. 2003, Woodhams \& Alford 2005, Sapsford et al. 2013). Hence, streams and other water bodies are central habitats in the ecology of the disease, particularly in rainforests where they may function both as habitats for reservoir hosts and as centres of transmission. Sapsford et al. (2013) recently demonstrated that the dynamics of $B d$ infection in stream-associated frogs at lowland sites can be affected by stream flows from upland sites, suggesting that the pathogen may be transmitted from uplands to lowlands by water flow.

The fungus cannot grow at temperatures above $28^{\circ} \mathrm{C}$ and dies above $30^{\circ} \mathrm{C}$ (Piotrowski et al. 2004, Stevenson et al. 2013). It is most strongly associated with declines in aquatic and riparian amphibians, especially stream-associated species at high elevations where water temperatures remain relatively cool year round (McDonald \& Alford 1999, Lips et al. 2003, Woodhams \& Alford 2005, Brem \& Lips 2008). Infection occurs in keratinized epidermal cells of postmetamorphic amphibians and in the mouthparts of tadpoles (Longcore et al. 1999, Berger et al. 2005). In tadpoles, infection often leads to degeneration of teeth and jaw sheaths (Rachowicz \& Vredenburg 2004, Venesky et al. 2010). Vulnerability to chytridiomycosis varies among species, but it is often lethal in postmetamorphic individuals (Collins \& Crump 2009). In postmetamorphic individuals, death occurs via cardiac arrest when a threshold of infection intensity is reached and electrolyte levels that are vital to muscle function become disrupted (Carey et al. 2006, Voyles et al. 2009). Compared to postmetamorphic amphibians, little is known about the effects of $B d$ infection on larval amphibians (Rachowicz \& Vredenburg 2004). However, recent laboratory experiments have indicated that it can impose fitness costs (Blaustein et al. 2005, Garner et al. 2009, Venesky et al. 2009).

Although $B d$ has been reported on dead algae and invertebrates (Johnson \& Speare 2003), on crayfish (McMahon et al. 2013), and on terrestrial reptiles (Kilburn et al. 2011), amphibians are thought to be its primary hosts (Berger et al. 2005). Stream-dwelling tadpoles often occur throughout the year (Alford 1999, Sapsford et al. 2013) and are susceptible to infection but do not usually die from it (Rachowicz \& Vredenburg 2004, Garner et al. 2009). Tadpole popu- lations can support a very high prevalence of infection (Puschendorf et al. 2011). Terrestrial juveniles and adults are more likely to succumb to chytridiomycosis or to lose their infections through immune function (Ramsey et al. 2010, McMahon et al. 2014) or exposure to a greater range of thermal conditions (e.g. daily and seasonal temperature fluctuations; Woodhams et al. 2008). Hence, stream tadpoles may serve as reservoir hosts, allowing $B d$ to persist in frog populations at times when prevalence is greatly reduced or even eliminated in terrestrial individuals. This may allow chytridiomycosis to drive populations of juveniles and adults to local extinction during epizootic outbreaks. Many researchers have found links between tadpoles and species declines. Streamdwelling species with a tadpole stage may be more likely to decline (McDonald \& Alford 1999, Lips et al. 2003). Species with a long-lived tadpole stage also appear to be more vulnerable (Bosch \& MartinezSolano 2006). Mathematical models of host-pathogen interactions during outbreaks predict that a high density of infected tadpoles increases the risk of local extinction (Briggs et al. 2005, Mitchell et al. 2008). Finally, infections that persist through metamorphosis, or transmission from larvae to recently metamorphosed conspecifics, may be a major cause of reduced survival and recruitment (Berger et al. 1998, Rachowicz \& Vredenburg 2004). Despite the potentially significant role of tadpoles in supporting and transmitting $B d$ during times of low terrestrial prevalence, little is known about how it is transmitted in natural streams or how it affects wild tadpoles. If tadpoles serve as reservoir hosts, the infection must be transmitted between them, and they must be able to survive infection long enough to infect other tadpoles and potentially also to metamorphose and carry the disease to the terrestrial environment. The aim of our study was to determine whether transmission occurred via zoospores carried downstream in a system where we knew there could be no contact between individual tadpoles and to examine in detail how tadpoles are affected by $B d$ infection in a semi-natural environment.

To increase our understanding of the ecology of the disease in larval amphibians, we conducted an experiment using larval green-eyed tree frogs Litoria serrata in semi-natural streamside channels. Our objectives were (1) to determine if downstream transmission of $B d$ occurs between tadpoles in a semi-natural environment and (2) to examine whether infection negatively affects tadpole growth rates, as would be expected if loss of mouthparts impedes their ability to feed. 


\section{MATERIALS AND METHODS}

\section{Study species and site}

Green-eyed tree frogs Litoria serrata inhabit tropical rainforests in northeastern Australia (Hoskin \& Hero 2008). They are associated with streams that offer a range of microhabitats, including fast- and slow-flowing sections with small pools, waterfalls, riffles and runs. Their tadpoles are members of the clasping ecomorphological guild and occupy slow-flowing stream environments in runs or pools (Altig \& Johnston 1989, Richards 2002). Tadpoles of the green-eyed tree frog occur year round, but their numbers peak during the summer and autumn (December to April; R. Alford pers. obs.). The species declined in association with the emergence of $B d$ in the early 1990s (Laurance et al. 1996, Berger et al. 1998, McDonald \& Alford 1999), but populations have subsequently recovered (Woodhams \& Alford 2005). Our experiments were conducted at Birthday Creek (19 $\left.00^{\prime} \mathrm{S}, 146^{\circ} 11^{\prime} \mathrm{E}\right)$, an upland rainforest stream in the Burdekin River catchment within the Paluma Range National Park at an elevation of $840 \mathrm{~m}$. The most common tadpoles in this stream are L. serrata (Richards \& Alford 2005).

\section{Detection of $B d$ infection}

We collected tadpoles from the creek and transported them to our facilities at James Cook University, where we housed them individually in plastic containers with aerated water at $20^{\circ} \mathrm{C}$ for $2 \mathrm{~d}$ while we determined their infection status. To test for the presence of $B d$, we used a PCR assay following the procedures developed by Boyle et al. (2004).
In tadpoles, infection occurs within the keratinized oral structures of the mouthparts and associated tissues (Marantelli et al. 2004). We gently swabbed each tadpole with a sterile rayon swab (Medical Wire and Equipment) 5 times horizontally across the upper and lower tooth rows and jaw sheath and 5 times vertically across all rows, for a total of 10 strokes. The tadpoles were handled with vinyl gloves that were changed between individuals to prevent mortality and disease transmission (Cashins et al. 2008). We extracted DNA from the swabs by immersing the tips in $50 \mu \mathrm{l}$ PrepMan Ultra (Applied Biosystems) and then beating them with silica beads twice for $45 \mathrm{~s}$, each time followed by centrifugation for $1 \mathrm{~min}$. The extraction tubes were incubated at $100^{\circ} \mathrm{C}$ for $10 \mathrm{~min}$ and then cooled at room temperature and centrifuged. We diluted the resulting extractions and ran them through a TaqMan® (Applied Biosystems) PCR assay (Boyle et al. 2004). These procedures were repeated at the end of the experiment described in the next subsection.

\section{Experimental design, conditions and timeline}

Our experimental apparatus diverted water from the creek through a polypropylene pipe to a header tank, from which it was distributed via individual hoses into slow-flowing artificial stream channels (Fig. 1). The water was filtered (approximately $1 \mathrm{~mm}$ mesh size) at the inlet of the reservoir and flowed at least $40 \mathrm{~m}$ between the intake and the time it entered one of the channels. The purpose of the filter was to prevent large items (e.g. leaves) from entering and clogging the system while still allowing passage of other suspended material. Each channel was $15 \mathrm{~cm}$

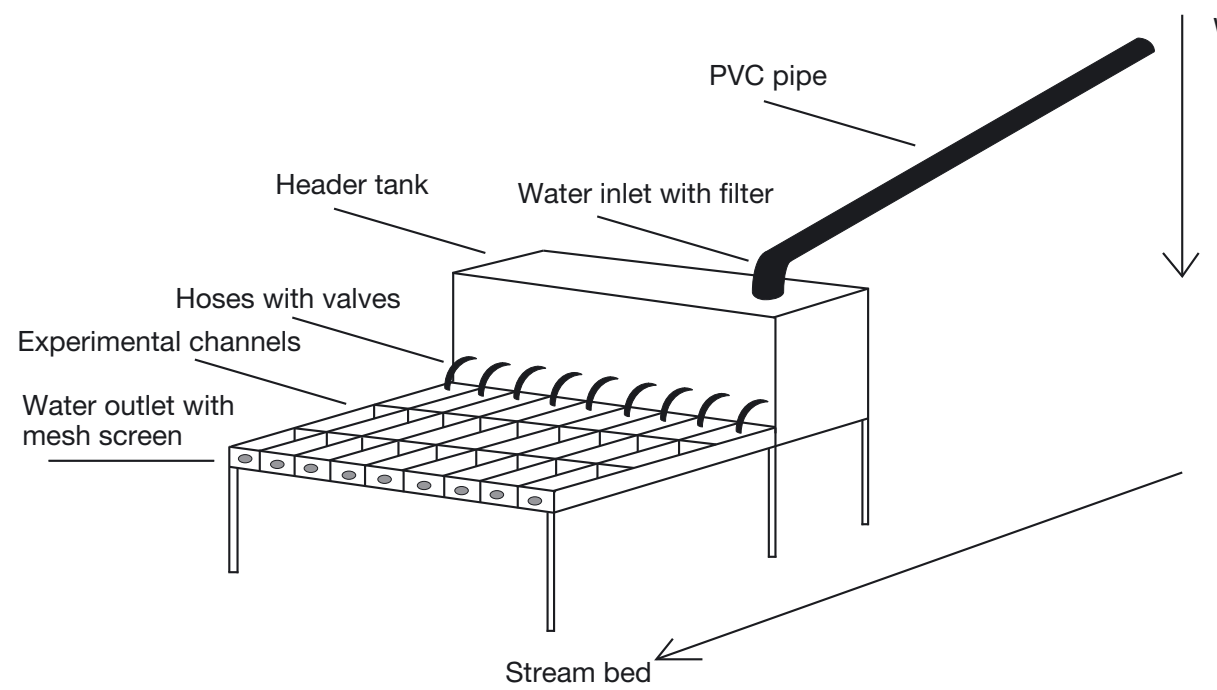

Waterfall

Fig. 1. Stream inflow, streambed, arrangement of the chambers and stream outflow of the experimental arena used at our study site in an upland tropical rainforest in north Queensland, Australia 
wide and $240 \mathrm{~cm}$ long and was partitioned by $1.0 \mathrm{~mm}$ mesh into three $80 \mathrm{~cm}$ long compartments, providing an upper, middle and lower stream section in each channel. Water levels and flow rates were controlled using valves connected to the hoses that fed water from the reservoir. For our experiments, each compartment contained several rocks removed and thoroughly washed from the adjacent streambed. The compartments were set up and water flow established on 1 November 2010, 2 d before experimental tadpoles were introduced. The apparatus is described more completely in Pearson \& Connolly (2000).

To determine whether $B d$ infection could be transmitted between tadpoles without physical contact between individuals, we introduced a single individual into each compartment in each channel. Infected individuals were introduced into a single upstream compartment in some channels; if uninfected individuals downstream of them became infected, this would indicate that the infection was acquired via waterborne zoospores. Some channels contained only uninfected animals, which served as controls for the possibility that infections might be acquired via incoming water or from the substrates introduced to the channels when the experiment was set up. The body mass and mouthpart condition of all tadpoles were measured at the start and end of the experiment to allow evaluation of the effects of infection. We did not provide food during the experiment because the filter at the inlet of the reservoir allowed fine suspended food particles to enter into the channels. Food also entered the channels from natural litterfall. Sediment thus settled quickly on the bottom of the channels, and we observed the tadpoles to feed from it.

Tadpoles were collected and sampled to determine their $B d$ infection status on 01 November 2010. The numbers of infected and uninfected tadpoles avail- able dictated the final design of our experiment. On 3 November 2010, we placed individual tadpoles in the artificial stream channels. In 5 channels, all 3 compartments each contained 1 tadpole. The individual in the first (most upstream) compartment was infected with $B d$. In 3 channels, interspersed between the ones containing infected tadpoles, uninfected individuals were placed in the first 2 compartments, to serve as controls for possible transmission via inflowing stream water. Altogether, we used 21 tadpoles, and the experiment ran for $21 \mathrm{~d}$.

\section{Effects of $\boldsymbol{B d}$ infection on body mass and mouthparts}

To examine whether $B d$ infection affected the growth rates of the tadpoles, we weighed them to the nearest milligram at the start and end of the experiment using a digital laboratory balance. Each time, this was done immediately after we swabbed the tadpoles for $B d$. After the end of the experiment, all tadpoles were euthanized and preserved in alcohol. We used enlarged photographs of the preserved tadpoles (Fig. 2) to calculate the percentage of the oral structures that were missing.

\section{Statistical analyses}

Data were analyzed using $\mathrm{R}$ version 2.15.2 ( $\mathrm{R}$ Development Core Team 2012). We compared the total numbers of tadpoles $(0,1$ or 2$)$ that became infected between the 2 treatments ( 2 tadpoles in separate compartments downstream from an infected individual or 2 tadpoles in separate compartments with no infected individual upstream) using a 2tailed Wilcoxon rank sum test, since our sample size
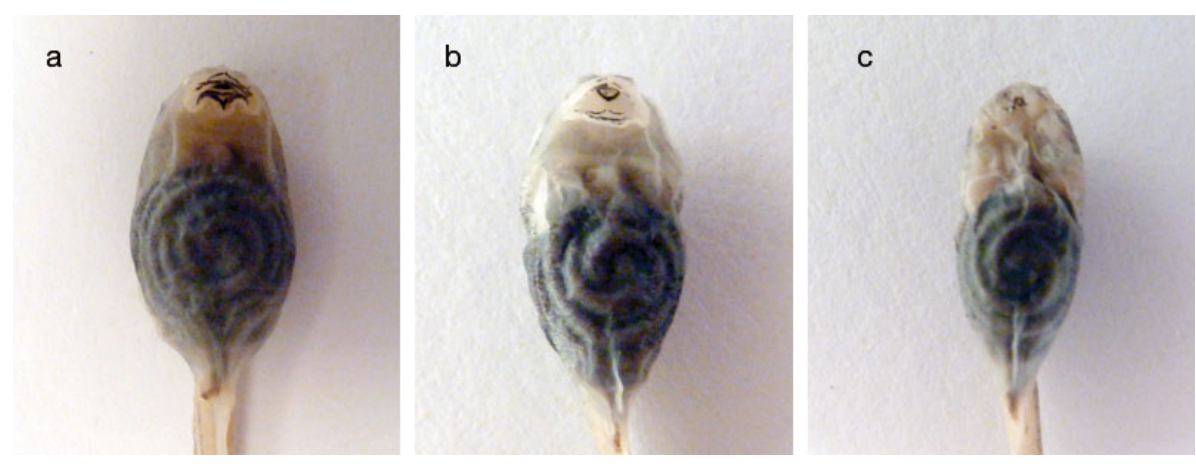

Fig. 2. Effects of Batrachochytrium dendrobatidis infection on the mouthparts of green-eyed tree frog tadpoles. (a) Healthy tadpole with complete mouthparts; 2 infected tadpoles with (b) partial and (c) nearly total loss of tooth rows and jaw sheaths. Note also the dissimilarity in body shapes reflecting differences in body mass. Photo credit: Mattias Hagman 
was small and consisted of count data. Older, larger individuals with greater cumulative exposure to the risk of transmission might be more likely to be infected, so it was possible that tadpoles that were infected at the start of the experiment were larger than uninfected tadpoles. This could have affected our interpretation of changes in mass and mouthpart loss. We tested this hypothesis by using a 2-tailed Wilcoxon rank sum test for differences in mass between initially infected and uninfected tadpoles. Tadpoles that returned negatives at the start of the experiment could have been false negatives or carried infections below detectable levels; however, this could not have been common, since none of the tadpoles that were not exposed to flow from a known infected individual tested positive at the end of the experiment.

We used Kruskal-Wallis tests to determine whether change in mass over the course of the experiment and mouthpart loss at the end of the experiment differed significantly between initially infected tadpoles, tadpoles that became infected during the experiment and tadpoles that remained uninfected throughout the experiment. When a Kruskal-Wallis test was significant, we used 3 pairwise Wilcoxon rank sum tests to determine which pairs of comparisons were significant at the Bonferroni-adjusted $\mathrm{p}$ value of 0.0167 . Although tadpoles reared in the same channel may not be statistically independent, potential channel effects could not have been confounded in any simple way with the effects we tested for, since the first 2 categories occurred together in channels, and analyses accounting for possible channel effects were not possible because of our small sample sizes.

\section{RESULTS}

\section{Patterns of $\boldsymbol{B d}$ transmission}

Our treatments affected the number of tadpoles that became infected by $B d$ (Table 1; Wilcoxon rank sum test, $W=1.5, \mathrm{p}=0.0500$ ). The 6 uninfected tadpoles placed in channels not containing an infected tadpole (the controls) did not become infected. A total of 7 of the 10 tadpoles placed downstream from an infected tadpole became infected (Table 1): neither of the 2 in Channel 8; 1 of the 2 in Channel 1 (the one in Compartment 3, farthest from the initially infected individual); and both individuals in Channels 3, 4 and 5 . All of the 5 initially infected tadpoles remained infected at the end of the experiment.
Table 1. Results of the transmission experiment. Treatments were randomly allocated to stream channels. In the 3 channels in which uninfected tadpoles were placed in the first 2 compartments of the stream channel (the control treatment), no individuals became infected. In the 5 channels in which an infected tadpole was placed in Compartment 1 and uninfected tadpoles were placed in Compartments 2 and 3, 7 downstream tadpoles became infected while only 3 remained uninfected. The single individual that became infected in Channel 1 was in the compartment farthest downstream, $80 \mathrm{~cm}$ from the infected individual

\begin{tabular}{|lcrc|}
\hline Channel & $\begin{array}{c}\text { No. of uninfected } \\
\text { tadpoles } \\
\text { per channel }\end{array}$ & $\begin{array}{c}\text { Infection } \\
\text { treatment }\end{array}$ & $\begin{array}{c}\text { No. of tadpoles } \\
\text { that became } \\
\text { infected }\end{array}$ \\
\hline 1 & 2 & Exposed & 1 \\
2 & 2 & Control & 0 \\
3 & 2 & Exposed & 2 \\
4 & 2 & Exposed & 2 \\
5 & 2 & Exposed & 2 \\
6 & 2 & Control & 0 \\
7 & 2 & Control & 0 \\
8 & 2 & Exposed & 0 \\
\hline
\end{tabular}

\section{Effects of $B d$ infection on body mass and mouthparts}

At initiation of the experiment, always infected tadpoles had somewhat but not significantly more initial mass than initially uninfected tadpoles (Wilcoxon rank sum test, $W=17, \mathrm{p}=0.0575$; Fig. 3a). The percentage mass change between the start and end of the experiment differed significantly among tadpoles that were always uninfected, tadpoles that became infected and those that were always infected (Kruskal-Wallis test, $\chi^{2}=14.8364, \mathrm{df}=2, \mathrm{p}=0.0006$; Fig 3b). Post-hoc pairwise comparisons using 2-tailed Wilcoxon rank sum tests at the Bonferroni-adjusted alpha level of 0.0167 showed that tadpoles that were always uninfected increased significantly more in mass change (always infected versus always uninfected, $W=45.0, \mathrm{p}=0.0009$; became infected versus always uninfected, $W=63.0, \mathrm{p}=0.0002$ ) than tadpoles that were always infected (Fig. $3 b$ ) and that tadpoles that became infected did not exhibit mass change at significantly different rates from those that were always infected ( $W=14.0, \mathrm{p}=0.6389$; Fig $3 \mathrm{~b}$ ).

The 3 classes of tadpoles also differed significantly in the degree of mouthpart loss at the end of the experiment (Kruskal-Wallis test, $\chi^{2}=8.303, \mathrm{df}=2, \mathrm{p}=$ 0.0157; Fig. 3c). Post-hoc pairwise comparisons using 2-tailed Wilcoxon rank sum tests at the Bonferroniadjusted alpha level of 0.0167 showed that mouthpart loss did not differ significantly between tadpoles that were always infected and those that were always 

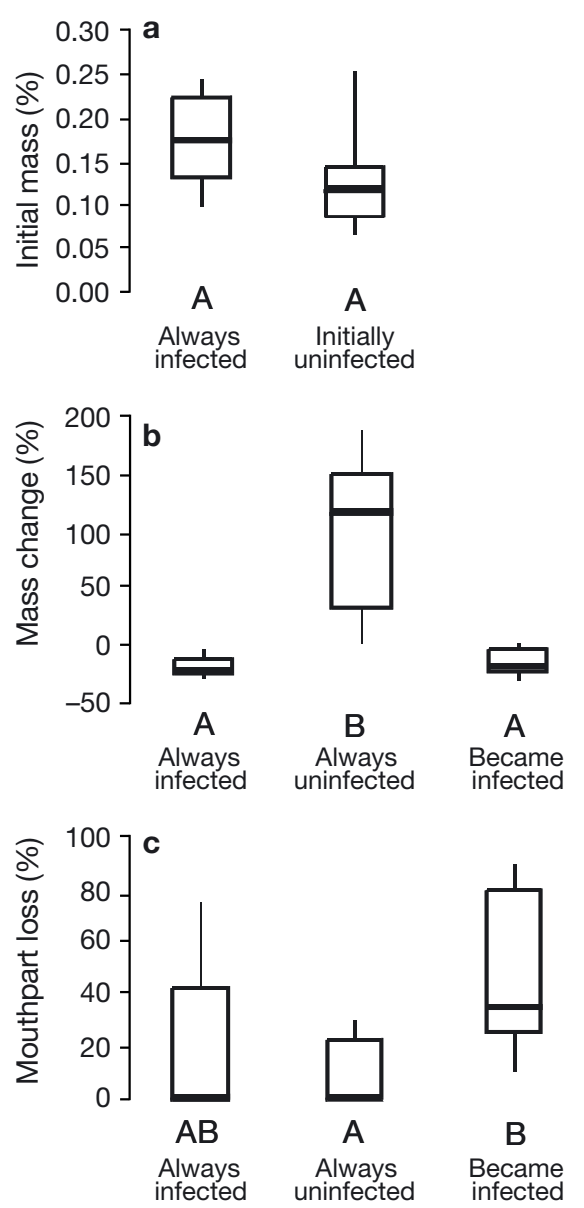

Fig. 3. Distributions of variables measured during the experiment. Horizontal lines within the boxes represent medians, box boundaries indicate lower and upper quartiles and whiskers show ranges. Letters above treatment labels indicate membership in groups that do not differ significantly. (a) Initial body masses of tadpoles that were either infected when collected (always infected) or initially uninfected. (b) Change in body mass between the start and end of the experiment for tadpoles that were always infected, those that were always uninfected and those that became infected during the experiment. (c) Percent mouthpart loss at the end of the experiment in tadpoles in each treatment

uninfected $(W=34.0, \mathrm{p}=0.9062)$. Tadpoles that became infected did not have significantly more mouthpart loss than those that were always infected $(W=36.5, \mathrm{p}=0.0243$; not significant at the Bonferroni-adjusted value of 0.0167 ). Tadpoles that became infected, however, did have significantly more mouthpart loss than those that were always uninfected $(W=6.0, \mathrm{p}=0.0060$; Fig 3c).

Examination of the relationship between percentage change in body mass during the experiment and extent of mouthpart loss at the conclusion of the experiment suggested that there was a possible trend, but we found no statistically significant relationship between these variables. When only data for the range of percentages of mouthpart loss including both infected and uninfected tadpoles were considered, it was evident that differences in mass change were related to infection status, not to mouthpart loss. We therefore did not perform a correlation analysis, since any correlation would have been artifactual.

\section{DISCUSSION}

Many anuran species that have declined during outbreaks of chytridiomycosis are associated with rainforest streams (Alford 2010). Hence, it is particularly important to understand the ecology of the disease in these habitats. The present study contributes new information on a transmission pathway for $B d$ and also shows how infection with $B d$ can affect tadpoles in the wild. It provides an ecologically realistic perspective and will serve as a building block for future research. Our results on the infection status of tadpoles at the start of the experiment indicated that infected tadpoles captured in natural habitat in early summer were somewhat (but not significantly) larger and more developed than uninfected tadpoles. Litoria serrata tadpoles overwinter as tadpoles (Richards \& Alford 2005) and are present at the field site all year; this, along with the fact that the tadpoles were captured early in the breeding season, suggests that infected tadpoles were substantially larger on average because many or most of them had overwintered as tadpoles and may have been infected because they had much greater cumulative exposure to infection risk. This agrees with Cashins (2009) and Sapsford (2012), who found very similar patterns in tadpoles of L. nannotis and L. rheocola in streams in the Australian Wet Tropics.

How $B d$ is transmitted and how it spreads within the environment are still poorly known (Alford 2010). Our results indicate that transmission between tadpoles can occur downstream via waterborne zoospores, even when individuals do not come into physical contact. To our knowledge, this study is the first to show downstream transmission in a seminatural stream habitat. Tadpoles became infected immediately adjacent to infected individuals and in compartments separated from them by $80 \mathrm{~cm}$. It is possible that individuals became infected sequentially; however, in Channel 1, the individual in the compartment farthest downstream became infected, although the individual in the intervening compartment did not. More than $50 \%$ of individuals in both 
types of downstream compartments became infected when an infected animal was in the most upstream compartment. Our results thus show that transmission to uninfected individuals downstream from infected ones can happen rapidly (within the $21 \mathrm{~d}$ duration of our experiment) and relatively commonly ( 7 of 10 exposed uninfected individuals became infected). It is possible that downstream transmission, in which zoospores can be transported passively by water flow, is more efficient than upstream transmission. Additional experiments will be needed to test for upstream transmission and examine this potential directional bias. Additional experiments would also be useful to measure how far downstream $B d$ zoospores can disperse. The fact that none of our control tadpoles became infected, although the water in the experimental apparatus was diverted from the stream from which all including the initially infected individuals had been collected, suggests that the density of infectious zoospores at least $40 \mathrm{~m}$ below any possible source was low.

It is thought that the mouthparts of stream-dwelling tadpoles are vital for grazing food from rock surfaces (Altig \& Johnston 1989). Mouthpart loss was significantly elevated in tadpoles that became infected during our experiment, providing strong evidence that substantial mouthpart loss can occur within a relatively short period following initial infection by $B d$ (Fig. 3c). In our experiment, recently infected tadpoles also grew much more slowly than initially similar-sized uninfected individuals that did not become infected (Fig. 3a,b). This could suggest that mouthpart loss caused by $B d$ infection caused growth to slow, which would be consistent with recent studies showing that $B d$ infection reduces foraging efficiency of anuran tadpoles by altering their feeding kinematics (Venesky et al. 2010, DeMarchi et al. 2015). However, newly infected tadpoles that had suffered low levels of mouthpart loss also appeared (although not statistically significant) to grow more slowly than uninfected tadpoles with similar levels of mouthpart loss. Our results thus suggest that at least some mouthpart loss sometimes occurs for reasons other than $B d$ infection, that $B d$ infection may reduce growth rate via mechanisms other than mouthpart loss (perhaps via direct toxicity, as demonstrated by McMahon et al. 2013), and that at least at lower levels, mouthpart loss may not greatly slow the growth of individuals.

The tadpoles we collected with pre-existing $B d$ infections were substantially, though not significantly, larger than uninfected tadpoles (Fig. 3a) and showed relatively low levels of mouthpart loss, similar to and not significantly greater than those we measured in tadpoles that were never infected (Fig. 3b). This result is similar to the results of Cashins (2009), who found that following loss of mouthparts and body condition soon after infection, $B d$-infected L. nannotis larvae appeared to re-grow mouthparts, gain body condition and resume growth despite remaining infected. We suggest that newly infected L. serrata tadpoles may show a similar pattern of initial loss of mouthparts and body condition, followed by mouthpart re-growth and recovery of body condition as the infection settles into a chronic state. The failure of the always infected tadpoles to grow during the experiment may have a different cause from that of the newly infected tadpoles. When collected, many of the always infected individuals were already at a size at which $L$. serrata tadpoles initiate metamorphosis (R. Alford pers. obs.). Once frog larvae reach that size and concomitant developmental stage, energy is diverted into development, and growth slows and eventually ceases (Alford \& Harris 1988). Another possible explanation is that $B d$ infection killed the smallest and weakest tadpoles. So, when we collected infected tadpoles from the field, only the larger animals that were able to survive infection were left. In any case, even if tadpoles can cope sufficiently with chronic infections to resume growth and development, it is likely that infection by $B d$ delays metamorphosis and could have negative carryover effects on adult fitness (Wilbur \& Collins 1973, Wilbur 1980, Fisher et al. 2009, Hagman et al. 2009). Ultimately, such effects at the individual level could affect population dynamics.

Previous studies (Briggs et al. 2005) have suggested that in lentic habitats, external infection and re-infection caused by zoospores from the external environment can control the intensity as well as the prevalence of $B d$ infections and may determine the fate of populations during epizootic outbreaks of chytridiomycosis. Our results indicate that over short distances, downstream transmission of $B d$ can occur via waterborne zoospores, even when individuals are not in physical contact. Sapsford et al. (2013) found that populations of frogs near lowland streams connected to upland streams by flow have higher and more stable prevalences of $B d$ infection than populations at lowland streams that do not receive flow from upland streams and suggested that one explanation for this could be drift of zoospores from higher elevation populations. This suggests that the same mechanisms may function in lotic habitats. We speculate that any management efforts that can reduce the prevalence of infections in tadpoles may be particularly effective if applied in headwater areas, which 
are not subjected to an influx of zoospores from upstream. Additional studies of in-stream infection dynamics are needed to test this hypothesis. Tests of upstream transmission would also be required.

Overall, our results agree well with the hypothesis that streams and other water bodies are central habitats in the ecology of the disease, particularly in rainforests, where they may facilitate transmission of the pathogen and harbor infected tadpoles that serve as reservoirs. The strong effects we documented on tadpole growth rates imply that infection in the larval stage may contribute to $B d$-associated declines. Although populations of L. serrata appear to have recovered to densities roughly similar to those encountered before the emergence of chytridiomycosis in the Australian Wet Tropics, populations of several other species have not, and many species that have declined in association with chytridiomycosis in other regions have also failed to recover. The effects of $B d$ infection in the larval stage may contribute to these effects. If this is the case, it is possible that short-term programs of intensive work to reduce the prevalence of larval $B d$ infection, particularly in headwater populations, could help sustain populations. Our preliminary results indicate that further studies into the infection dynamics and management of $B d$ in stream habitats may prove essential to understanding and managing chytridiomycosis.

Acknowledgements. We are grateful to Sally Hagman for her courage and resoluteness. Rebecca Webb provided assistance in the laboratory, and Sara Bell, Richard Pearson and Niall Connolly provided helpful advice. Funding was provided by an Australian Research Council Discovery Grant (DP0986537) and a grant from the Mazda Foundation. Ethics were approved by the James Cook University Animal Ethics Committee (approval number A1316). The experiment was performed under a permit from the Queensland Department of Environment and Resource Management (WITK03070508).

\section{LITERATURE CITED}

Alford RA (1999) Ecology: resource use, competition, and predation. In: McDiarmid RW, Altig R (eds) Tadpoles: the biology of anuran larvae. University of Chicago Press, Chicago, IL, p 240-278

Alford RA (2010) Declines and the global status of amphibians. In: Sparling DW, Lindner G, Bishop CA, Krest SK (eds) Ecotoxicology of amphibians and reptiles, 2nd edn. CRC Press, London, p 13-46

- Alford RA, Harris RN (1988) Effects of larval growth history on anuran metamorphosis. Am Nat 131:91-106

> Alford RA, Richards SJ (1999) Global amphibian declines: a problem in applied ecology. Annu Rev Ecol Syst 30: 133-165
Altig R, Johnston GF (1989) Guilds of anuran larvae: relationships among developmental modes, morphologies, and habitats. Herpetol Monog 3:81-109

Berger L, Speare R, Daszak P, Green DE and others (1998) Chytridiomycosis causes amphibian mortality associated with population declines in the rain forests of Australia and Central America. Proc Natl Acad Sci USA 95: 9031-9036

- Berger L, Speare R, Hines HB, Marantelli G and others (2004) Effect of season and temperature on mortality in amphibians due to chytridiomycosis. Aust Vet J 82: 433-439

Berger L, Hyatt AD, Speare R, Longcore JE (2005) Life cycle stages of the amphibian chytrid Batrachochytrium dendrobatidis. Dis Aquat Org 68:51-63

Blaustein AR, Romansic JM, Scheessele EA, Han BA, Pessier AP, Longcore JE (2005) Interspecific variation in susceptibility of frog tadpoles to the pathogenic fungus Batrachochytrium dendrobatidis. Conserv Biol 19:1460-1468

> Bosch J, Martinez-Solano I (2006) Chytrid fungus infection related to unusual mortalities of Salamandra salamandra and Bufo bufo in the Penalara Natural Park, Spain. Oryx 40:84-89

Boyle DG, Boyle DB, Olsen V, Morgan JAT, Hyatt AD (2004) Rapid quantitative detection of chytridiomycosis (Batrachochytrium dendrobatidis) in amphibian samples using real-time Taqman PCR assay. Dis Aquat Org 60:141-148

Brem FMR, Lips KR (2008) Batrachochytrium dendrobatidis infection patterns among Panamanian amphibian species, habitats and elevations during epizootic and enzootic stages. Dis Aquat Org 81:189-202

Briggs CJ, Vredenburg VT, Knapp RA, Rachowicz LJ (2005) Investigating the population-level effects of chytridiomycosis: an emerging infectious disease of amphibians. Ecology 86:3149-3159

- Carey C, Bruzgul JE, Livo LJ, Walling ML and others (2006) Experimental exposures of boreal toads (Bufo boreas) to a pathogenic chytrid fungus (Batrachochytrium dendrobatidis). EcoHealth 3:5-21

Cashins SD (2009) Epidemiology of chytridiomycosis in rainforest stream tadpoles. PhD thesis, James Cook University, Townsville

Cashins SD, Alford RA, Skerratt LF (2008) Lethal effect of latex, nitrile, and vinyl gloves on tadpoles. Herpetol Rev 39:298-301

Collins JP, Crump ML (2009) Extinction in our times. Global amphibian decline. Oxford University Press, New York, NY

DeMarchi JA, Gaston JR, Spadaro AN, Porterfield CA, Venesky MD (2015) Tadpole food consumption decreases with increasing Batrachochytrium dendrobatidis infection intensity. J Herpetol (in press)

Fisher MC, Garner TWJ, Walker SF (2009) Global emergence of Batrachochytrium dendrobatidis and amphibian chytridiomycosis in space, time, and host. Annu Rev Microbiol 63:291-310

Garner TWJ, Walker S, Bosch J, Leech S, Rowcliffe JM, Cunningham AM, Fisher MC (2009) Life history tradeoffs influence mortality associated with the amphibian pathogen Batrachochytrium dendrobatidis. Oikos 118: 783-791

> Hagman M, Hayes RA, Capon RJ, Shine R (2009) Alarm cues experienced by cane toad tadpoles affect postmetamorphic morphology and chemical defences. Funct Ecol 23:126-132 
Hoskin C, Hero JM (2008) Rainforest frogs of the wet tropics, north-east Australia. Griffith University, Southport

> Johnson ML, Speare R (2003) Survival of Batrachochytrium dendrobatidis in water: quarantine and disease control implications. Emerg Infect Dis 9:922-925

Kilburn VL, Ibáñez R, Green DM (2011) Reptiles as potential vectors and hosts of the amphibian pathogen Batrachochytrium dendrobatidis in Panama. Dis Aquat Org 97: 127-134

Laurance WF, McDonald KR, Speare R (1996) Epidemic disease and the catastrophic decline of Australian rainforest frogs. Conserv Biol 10:406-413

Lips KR, Reeve JD, Witters LR (2003) Ecological traits predicting amphibian population declines in Central America. Conserv Biol 17:1078-1088

Lips KR, Brem F, Brenes R, Reeve JD and others (2006) Emerging infectious disease and the loss of biodiversity in a Neotropical amphibian community. Proc Natl Acad Sci USA 103:3165-3170

Longcore JE, Pessier AP, Nichols DK (1999) Batrachochytrium dendrobatidis, a chytrid pathogenic to amphibians. Mycologia 91:219-227

Marantelli G, Berger L, Speare R, Keegan L (2004) Distribution of the amphibian chytrid Batrachochytrium dendrobatidis and keratin during tadpole development. Pac Conserv Biol 10:173-179

McDonald KR, Alford RA (1999) A review of declining frogs in northern Queensland. In: Campbell A (ed) Declines and disappearances of Australian frogs. Environment Australia, Canberra, p 14-22

McDonald KR, Mendez D, Muller R, Freeman AB, Speare R (2005) Decline in the prevalence of chytridiomycosis in upland frog populations in north Queensland, Australia. Pac Conserv Biol 11:114-120

McMahon TA, Brannelly LA, Chatfield MW, Johnson PT and others (2013) Chytrid fungus Batrachochytrium dendrobatidis has nonamphibian hosts and releases chemicals that cause pathology in the absence of infection. Proc Natl Acad Sci USA 110:210-215

McMahon TA, Sears BF, Venesky MD, Bessler SM and others (2014) Amphibians acquire resistance to live and dead fungus overcoming fungal immunosuppression. Nature 511:224-227

Mitchell KM, Churcher TS, Garner TWJ, Fisher MC (2008) Persistence of the emerging pathogen Batrachochytrium dendrobatidis outside the amphibian host greatly increases the probability of host extinction. Proc R Soc B 275:329-334

Pearson RG, Connolly NM (2000) Nutrient enhancement, food quality and community dynamics in a tropical rainforest stream. Freshw Biol 43:31-42

Piotrowski JS, Annis SL, Longcore JE (2004) Physiology of Batrachochytrium dendrobatidis, a chytrid pathogen of amphibians. Mycologia 96:9-15

Puschendorf R, Hoskin CJ, Cashins SD, McDonald K, Skerrat LF, VanDerWal J, Alford RA (2011) Environmental refuge from disease-driven amphibian extinction. Conserv Biol 25:956-964

Rachowicz LJ, Vredenburg VT (2004) Transmission of Batrachochytrium dendrobatidis within and between amphib-

Editorial responsibility: Louise Rollins-Smith,

Nashville, Tennessee, USA ian life stages. Dis Aquat Org 61:75-83

> Ramsey JP, Reinert LK, Harper LK, Woodhams DC, RollinsSmith LA (2010) Innate and adaptive immune defenses against a fungus linked to global amphibian declines in the South African clawed frog, Xenopus laevis. Infect Immun 78:3981-3992

R Development Core Team (2012) R: a language and environment for statistical computing. R Foundation for Statistical Computing, Vienna. www.r-project.org

Richards SJ (2002) Influence of flow regime on habitat selection by tadpoles in an Australian rainforest stream. J Zool Lond 257:273-279

Richards SJ, Alford RA (2005) Structure and dynamics of a rainforest frog (Litoria genimaculata) population in northern Queensland. Aust J Zool 53:229-236

Richmond $\mathrm{JQ}$, Savage AE, Zamudio KR, Rosenblum EB (2009) Toward immunogenetic studies of amphibian chytridiomycosis: linking innate and acquired immunity. Bioscience 59:311-320

Sapsford SJ (2012) Population and disease dynamics of the amphibian chytrid fungus in the stream-associated frog Litoria rheocola. MSc thesis, James Cook University, Townsville

Sapsford SJ, Alford RA, Schwarzkopf L (2013) Elevation, temperature, and aquatic connectivity all influence the infection dynamics of the amphibian chytrid fungus in adult frogs. PLoS ONE 8:e82425

> Stevenson LA, Alford RA, Bell SC, Roznik EA, Berger L, Pike DA (2013) Variation in thermal performance of a widespread pathogen, the amphibian chytrid fungus Batrachochytrium dendrobatidis. PLoS ONE 8:e73830

- Stuart SN, Chanson JS, Cox NA, Young BE, Rodrigues AS, Fischman DL, Waller RW (2004) Status and trends of amphibian declines and extinctions worldwide. Science 306:1783-1786

Venesky MD, Parris MJ, Storfer A (2009) Impacts of Batrachochytrium dendrobatidis infection on tadpole foraging performance. EcoHealth 6:565-575

Venesky MD, Wassersug RJ, Parris MJ (2010) Fungal pathogen alters the feeding kinematics of larval anurans. J Parasitol 96:552-557

> Voyles J, Young S, Berger L, Campbell C and others (2009) Pathogenesis of chytridiomycosis, a cause of catastrophic amphibian declines. Science 326:582-585

- Wilbur HM (1980) Complex life cycles. Annu Rev Ecol Syst 11:67-93

- Wilbur HM, Collins JP (1973) Ecological aspects of amphibian metamorphosis non-normal distributions of competitive ability reflect selection for facultative metamorphosis. Science 182:1305-1314

- Woodhams DC, Alford RA (2005) Ecology of chytridiomycosis in rainforest stream frog assemblages of tropical Queensland. Conserv Biol 19:1449-1459

Woodhams DC, Alford RA, Marantelli G (2003) Emerging disease of amphibians cured by elevated body temperature. Dis Aquat Org 55:65-67

Woodhams DC, Alford RA, Briggs CJ, Johnson M, RollinsSmith LA (2008) Life-history trade-offs influence disease in changing environments: strategies of an amphibian pathogen. Ecology 89:1627-1639

Submitted: June 3, 2014; Accepted: June 22, 2015

Proofs received from author(s): August 7, 2015 